tion of bromides. The prompt effects of Sammter's treatment of erysipelas by carbolic acid injections, are well known. The superior effects of the treatment of syphilis, by hypodermic injection of cyanide and bichloride of mercury and chloride of gold and sodium are striking, as we all know. Dr. Zumbali, of Rome, found hypodermic injections of chlorodyne in profuse diarrhoea particularly superior to its administration by the mouth. The hy podermic injection of ergot for the relief of hæmoptysis is another example. This agent, administered in considerable quantity by the mouth, will often fail, whereas one, or at most two, hypodermic injections of $\frac{1}{T^{1}}$ or $\frac{1}{5} \mathrm{gr}$. of ergotin will generally stop a severe attack. Dig. italis also acts upon the cells and vascular system more certainly when so administered. I may also mention the beneficial effects of strychnia used hypodermically, in typhoid conditions. That animal poisons can be neutralized in the body, I believe, will soon be more generally deinonstrated. The experience of Tyndall, of New York, in the vaccination process for the cure of tuberculosis, promises well. Hemmeter has stopped the course of diphtheria by the vaccination of the patient with an erysipelas toxine; and Prof. Grancher states that persons suffering from tenia tonsurans are immune from diphtheria. This would seem toshow that there must be a sort of antagonism or isomerism between animal and chemical poisons; and why may not more universal application be made of this principle, with a view of obtaining more specific therapentic agents and effects? The ethereal oils, on account of their diffusable antiseptic properties, are undoubtedly applicable to the neutralization of disease when used hypodermically, and may prove yet of great value in the zymotic diseases. We are now engaged in using some of them in this way, and find that they actually provoke the liquefaction of effused products. We are also experimenting with members of the benzoin and formic acid series, and the toluidines, in an endeavor to learn their action on metabolism and disease poisons. Dr. Emil Schutz believes that drugs act topically on the secretions by precipitating albumin. He also demonstrated, by cases, that tannic acid may produce urticaria by external application alone. Galezowski, of Paris, has lately discovered a new bacteriacide, by the decomposition of an aniline dye, which has the same properties as pyoktania on the tissties. In this direction we may look for brilliants results, on acconnt of the action of these substances on albuminates. My chief object is to awaken a more general interest in physiological and pathological chemistry, to the end that we may as speedily as possible acquire a scientific chemical therapy, and thus release her from the dungeon of empiricistu, where she has been imprisoned with so little light these many years.

\section{THE ADDRESS ON STATE MEDICINE.}

Read by Titier at the Forty-second Annual Meeting of the Americars Medical Association, held at Washington, D.C., May, I895.

BY W. I. SCHENCK, M.D.,

IOF TOPFKA, KANSAS, P'ROFESSOR OF STATE MEDICINE AND PATHOLOGY IN THE KANSAS MEDICAL COLLEGE.

Mr. President and Fellows of the American Medical Association:-While I appreciate the honor of the Address on State Medicine, I comprehend the difficulty of doing honor to a position so ably filled by Dr. Henry I. Bowditch, Dr. J. L. Cabell, Dr. George H. Rohè, and other distinguished physicians and sanitarians. I am as another Ruth in the already well gleaned fields of Boaz.

If the importance of the subject assigned to me required emphasis, it could receive no stronger than was given to it at the last meeting of the Association, when its honored president. Dr. E. MI. Moore, devoted much of his address to it, while the distinguished Father of the Association, Dr. N. S. Davis, in the Address on General Medicine, dwelt upon the same theme.

State Medicine, narrowly defined, is the control of disease through legislative enactments. In its broader signification it includes all that tends to the prevention of disease and to the fullness of life.

The various departments of medicine exist because health is more to be desired than disease. That department then which preserves health and prevents the development of disease is the peer of any whose function is to remove disease and restore health. Hitherto cure has been the chief thought of the scientific physician. Henceforth prevention will be his noblest theme.

While no new discoveries have been made in this important field during the past year, there has been a notable advance along the whole line, and the importance of aseptic and antiseptic conditions has been more and more pronounced.

There has been throughout the year a very commendable diffusion of knowledge by sanitary conventions and journals, and through State Boards of Health, and perhaps some good has been effected through the laws that make hygiene, and especially the relation of alcoholics to disease, a part of our public school education, though it has often proved so small a part that it might have been elininated without any appreciable change. Those who instruct must understand what they assume to teach before satisfactory results can obtain, and the public must comprehend the importance of physiology and hygiene before teachers will acquire the necessary knowledge. In America health, both public and private, has generally been left to take care of itself, and the scientists who devote their lives to its protection and development have too often been deemed impracticable cranks. Cure men of injuries and

In account of the unavoidable absence of its author. 
diseases and they will at least load you with gratitude; save them from injury and disease, and your service is beneath consideration, and while governments have been disposed to pay and honor those rendering valuable service in other departments of life, too often neitber pay nor honor has been awarded the sanitarium. Thus the first English army sent to the Crimea was decimated through want of sanitary care. With the second was sent a special sanitary commission, and after the campaign it returned in better sanitary condition than existed among the troops at home. The government crowned with honors the officers through whose neglect the first army was lost, but did not even commend those through whose wisdom the second was saved. Whilst this course has been the rule, during the year, Germany has made a commendable advance by conferring upon Koch a Baronetcy for distinguished service in the field of preventive medicine. In America, most of the States expect scientists to devote their lives to sanitation, on health boards and elsewhere, without fee or hope of reward, and to save the community from disease without adequate legal authority. Perhaps when sanitarians charge for their services they will be considered valuable, as mankind are disposed to estimate the value of every article at what it brings in the market. While practical sanitation is always a philanthropy it is never a charity. Scarce any other service yields so valua. ble a return. "An ounce of prevention is worth a pound of cure."

While in sanitary science many fields remain unexplored, and some differences exist, it is far in advance of its legally authorized application, and far enough advanced to see that the truth is within reach, and that few diseases are not amena. ble to its methods. If legal enactments for the preservation of health and life, were abreast with sanitary knowledge, the United States would annutally save vast sums of money, thousands of years of productive labor and thousands of hinman lives. The recent advance in the department of medical education is full of encouragement. Since the organization of this Association, fortyfour years ago, the burden of its prayer has been a higher standard of medical education. After twenty years of such effort, a committee, oom posed of its most eminent members, Drs. Gross, Bell, Condè, Pope and Bigelow, reported, "Its efforts have hitherto failed to produce any very great practical results;" and at the same meeting, another committee of equally distinguished physicians, Drs. Alfred, Stille and N. S. Davis, reported resolutions in favor of a better education as a pre-requisite to matriculation, and attendance upon three annual graded courses of medical instruction before admission to examination for a degree. During the past two decades the praying and resolving has gone steadily for- ward, ably seconded by the American Academy of Medicine, yet, judging from a paper read before that body last year by Dr. Dunglison, these more than forty years of prayer have fallen short of the Throne.

The statistics of the past year are, however, very encouraging. According to the excellent report of that eminent sanitarian, Dr. John $\mathrm{H}$. Rauch, in I882, only forty-five colleges in the United States required any educational qualification for matriculation, now 129 require at least a good English education. In I882, only twenty-two, and some of these relapsed, required three full courses of lectures of six months each; now there are eighty-five, one-fourth of them having been added, with others that have taken action since the publication of the report, during the past year. In 1882 , only 52 colleges had a chair in State Medicine. In I89I, there is such a chair in I I 7 colleges. "Nothing succeeds like success." Nothing demonstrates the power of prayer like the demonstration. When we move forward toward the answer it comes with quickening power. Until then it remains

"The hidden motion of a fire Within the human breast."

How much the action of the Illinois State Board of Health, requiring a three years' graded course as a pre-requisite to the acceptance of diplomas, and the results of the examining Boards of Virginia, North and South Carolina, Minnesota, New Jersey and Alabama had to do with hastening the answer, we will not stop to inquire, but I think we will all approve their action.

This advance, wherever honestly made, will tend to unify medical knowledge and destroy medical sects. "He who knows it half speaks much and is always 'wrong." Those who rest on their materia medicas, and antagonize the regular profession, which seeks to look at therapeutic action from every rational standpoint, though only as one to an hundred, are chiefly known by their clamor for equal representation on public boards, as though there could be a homœopathic hygiene, an eclectic etiology or a Christian science chemistry. Therapeutics is the roof that corers the temple; necessary to the temple, valueless without it. When the sciences from which spring both prevention and cure, are taught in graded courses, and absorb the thought of the physician, he will not thrust himself outside the pale of scientific medicine for such irrational dogmas as Ars., Bel., Bry., etc., cure whatever is set opposite them in the "Symptoneum Codex" of Hahnnemann.

While the marvelous progress of this last quarter of the century has in many departments of life created contempt for the slower methods of education, in medicine, notwithstanding the tendency to the development of specialties, there has been an increased demand for good work, 
thorough work, from all who cross its portals, both because there has been a truer conception of the length and breadth and depth of medical science, and a higher appreciation of the value of human life.

And we may well notice and commend the recent evidences among the people of increasing faith and interest in this department of medicine, manifested by such substantial methods as the gift of Henry C. Lea, of Philadelphia, the effort, with Mrs President Harrison at its head, to endow a Medical Department at Johns Hopkins, and the kind words of Mrs. Gen. John A. Logan, in the Home Journal, in favor of endowing a med. ical department to the University about to be established at Washington.

As the broader possibilities of State Medicine become more and more demonstrable its relations to political economy and true statesmanship are more apparent.

It is unnecessary to recount before this Association the loss the nation sustains through preventable diseases, or the methods by which they may be prevented. While there may be errors in diagnosis, and while sanitary methods may not be infallible, it is the duty of the government to apply sanitary knowleage as fast as developed, and to develop sanitary science. If in its life destroying service it rightly says "Better that ten guilty men escape than that one innocent man perish," in its life saving service it may well say, better an hundred innocent detentions than that one infection laden person scatter yellow fever, cholera or small-pox, disease and death, throughout the land, especially now that quarantine has ceased to mean forty days and forty nights of fasting and prayer, but only disinfection and detention until the period of incubation has passed. If the citizen is entitled to protection against injury and death, accidental or designed, he is equally entitled to protection against the more numerous and dangerous foes, that he can neither foresee nor avoid, whose poisons enter his body with necessary air, water and food.

Every intelligent sanitarian and statesman understands the power of State Medicine to save from disease and death those for whom the State exists. Scarce two centuries have passed since small pox ravaged the earth in winter, and various plagues decimated it in summer. In London, then perhaps the most highly civilized city in the world, with a population of only half a million, during the winter months from one thousand to fifteen hundred per week perished from small-pox, taking its victims from among all classes. It robbed William the Conqueror of his beloved Queen and filled potters fields from the homes of the poor, and as the statesman and historian, Macaulay, has graphically said:

That disease over which science has since achieved a succession of glorious and beneficent victories was then the most terrible of all the ministers of death. The havoc of the plague had been far more rapid, but the plague had visited our shores only twice within living memory; and the small-pox was always present, filling the churchyards with corpses, tormenting with constant fears all whom it had not stricken, leaving on those whose lives it spared the hideous traces of its power-turning the babe into a changeling at which the mother shuddered, and making the eyes and cheeks of the betrothed maiden objects of horror to the lover.

During the summer of different years from eight to ten thousand a week died of the plague, and when the city was not visited by special pests and plagues, the death-rate exceeded that of the modern London by more than forty per thousand, nearly twice the proportion that died last winter in Chicago. But this is not wholly a history of past ages. Wherever the same unsanitary conditions are permitted to obtain we still hear the tramp of the White Horse. Only two decades ago the yellow fever destroyed in our own Mem. phis an equally large proportion of lives.

The committee appointed by the Forty-seventh Congress to investigate and report the best means of preventing the introduction and spread of epidemic disease, reported:

In the yellow ferer epidemic of 1878 , which raged so fearfully and fatally at New Orleans, Memphis, Holly Springs and Grenada, and extended far up the Ohio River, and to many other places, the actual loss to the people of the United States in the element of material wealth, to say nothing of impaired health and loss of life, is variously estimated by those best informed on the subject, at from $\$ 100,000,000$ to $\$ 200,000,000$.

President Hayes, in his message to Congress, December, 1878 , said :

It is impossible to estimate, with any approach to ac. curacy, the loss to the country occasioned by this epidemic. It is reckoned by hundreds of nillions of dollars.

Abont one hundred thousand cases are believed to have occurred, of which about twenty thousand, according to intelligent estimates, proved fatal.

In a report made by the very efficient Secretary of the Michigan State Board of Health, Dr. Henry B. Baker, he says :

The annual saving of life has amounted to eleven hundred lives, representing seven thousand cases of sickness. Estimating each of these lives at only $\$ 500$ each, about half the value of an adult slave, and you have an annual saving of $\$ 550,000$. This the known saving from three diseases only.

Averaging the time that each of these seven thousand cases would have been unable to work at a fortnight, and there was an annual saving of 270 years of productive labor. Thus we begin to see the possibilities of State Medicine. If such results can obtain with crude and imperfect sanitary laws, hindered by State limitations, and in a State so illy appreciating these benefits that its Governor could formally recommend that the Board through whose efforts the results were obtained be abolished, what may we not hope as sanitary science and law develop, when the people appreciate their importance, and when the 
National Government efficiently coöperates with the several States?

But what a comment on the intelligence of the people, when the Governor of a great State falls so far short of true statesmanship that he can recommend the abolishment of a Board that, through its most efficient Secretary, has produced such results.

Take one other illustration of what can be done, of what should be done, through State Medicine: Under the improved sanitary conditions of London in I888, its deaths were 18.5 per 1,000. In the City of New York they were 25.9 . Both in climate and location nature has done more for New York than for London, and its death-rate should be less. If, with the city of Brooklyn, in every way similarly situated, it was reduced to that of London, there would be an annual saving of 15,988 lives, and if two persons should be continuously sick for each one dying, there would, by reducing the sick-rate to that of London, be an annual saving of nearly 32,000 years, and if the expetation of these lives was counted, what innumerable years would be saved, to say nothing of the expense of this excessive sickness and death, or of its suffering and sorrow. If this in New York alone, what of the National loss that State Medicine, properly applied, would save? Is the statesman wise, is the legislator a statesman or a philanthropist who permits this preventable loss of life and labor?

One of America's greatest men has described this as a Government "of the people, by the people, for the people," a nation where all power emanates from the people, and where all power not delegated to the General Government remains with the States, the intent being to delegate all power that the individual States cannot efficiently exercise. We are a nation of nations, with the grandest conceptior of rights, and the broadest provision for their protection known to man, assuming that "all men are created equal," not physically, intellectually or morally, but equal before the law, possessing an equal right to exercise and enjoy every natural right, an equal right to "life, liberty and the pursuit of happiness." Life and all its possibilities first, for in its preservation lie all other rights, and in its development, physically, intellectually and morally, all the best interests of the individual and the State, and liberty, without which life has little value - not liberty to do wrong, for no one possesses a natural, or can acquire a political right to advance his own at another's expense ; not liberty " to secure the greatest good to the greatest number," but liberty to attain the greatest possible good without injury to another.

This principle not only lies at the foundation of State Medicine, but of all good government.

At the organization of this Government various departments were created, all looking toward the development and protection of its varied interests. While we concede the importance of all these and of those created through the development of other interests, we naturally inquire for whom do they, for whom does the State exist? Is the thing created superior to those for whom it was created? Is not the health, the development, the life of the people its highest interest? Surely the treasures about their hearthstones, the lives of friends and neighbors, are more dear to the people than either commercial or financial interests, or " the cattle upon a thousand hills."

While all civilized nations have recognized the value of life, inflicting their severest punishment upon those who wantonly and maliciously destroy it, no adequate provision has ever been made for its protection against the causes by which it is constantly being destroyed. Is there not inconsistence in laws that destroy the life of him who wantonly destroys the life of another, while for each life thus destroyed they permit the destruction of an hundred or a thousand by preventable disease. If life is the highest interest of the nation, the dearest right of the citizen, the nation that fails to make every possible provision for its protection is inexcusable. Is a life taken by the stiletto or the bullet a greater loss to the nation, to the individual or to his friends, than when destroyed by pestilence or plague?

The National Government has recognized from its organization its authority and power to control disease, but lack of sanitary knowledge on the part of the legislator, whose education has not included sanitary science, has made medical legislation inefficient, while those selected to administer the law have too often been appointed for party purposes.

In February, I776, Congress authorized the President to assist the States in preventing the admission of disease from foreign countries. Three years later the authority was extended and placed under the control of the Treasury Department, not, it would seem, from any just appreciation of the importance of saving life, or from any natural relation between health and finance, but because quarantines interfere with commerce, and commerce was a source of revenue, and so revenue has ever been deemed better than health by the legislator.

In 1798 , the Marine-Hospital Service was organized, its purpose being to make provision for a class of citizens who served the nation on the high seas, but who were homeless when at home. For the same reason this too was placed under the care of the Treasury.

With a few unimportant provisions the status of State Medicine remained unchanged for more than half a century. After Asiatic cholera had thrice visited our shores, carrying death wherever it went, and after civil war had more fully demonstrated the relations of medicine to public health, 
Congress authorized the Secretary of the Treasury to adopt such measures as would guard the nation against another invasion of cholera, and placed at its disposal an ample fund for the purpose, but, as if doubting the power or the wisdom of pre ventive measures, it only provided for its expenditure during the seven months intervening between May 26, I856, and January I, I 867. Though the hastily and imperfectly organized measures did not keep the disease from the country, they robbed the destroyer of his accustomed victories, and il. lustrated the possibilities of State Medicine.

Ten years later Congress authorized the application of preventive medicine to the District of Columbia, and this beautiful city was lifted out of the mud and transformed from one of the most unsanitary to one of the most healthy cities in the world.

Stimulated by the ravages of yellow fever, in 1878 Congress provided for a Health Commis. sioner for the District, and a health officer at a salary of $\$ 3,000$, and the same year an Act was passed requiring the Surgeon-General of the Marine-Hospital Service to make rules for certificates by foreign consuls, showing the condition of vessels and cargoes bound for the United States.

Hitherto all action looking to the application of State Medicine had been indirect, both National and State Legislatures fearing, apparently, to acknowledge its power.

In 1879 Acts were passed creating a National State Board of Health, defining its powers, and authorizing it to prevent the introduction of contagious and infectious diseases, its most important feature being the acknowledgment of State Medicine as a life-saving scrvice. Hitherto it had been a "penny wise" affair, placed under the Treasury and created to save money. The $\mathrm{Na}$ tional Board of Health was a political acknowledgment of the value of human life, and was required to report directly to the President of the United States. Though, like many of the State Boards, which were the prophets of its birth, it was created under a pressure that convicted without convincing the legislator, many of its provisions were crude and imperfect. With the battle on, it was thrown into action with the information and order of General _- _ : "There is good fighting all along the line. Go in anywhere," but it achieved a success that will make it memorable in the history of State Medicine. Working in harmony with local boards of health, it strengthened their arms, and carried hope to their people, and changed the plague-stricken Memphis from a lazaretto to one of the healthiest cities of the South. In addition to illustrating the control of sanitary science over the great American plague, it published many valuable scientific papers and demonstrated the possibilities of preventive medicine.

While great credit is due to all connected with it, its powers were too limited and ill-defined and it lacked the single and forceful head, as essential in our conflict with the hidden foe that is ambushed in the dark lanes and alleys of our cities, and in every swamp and bayou, as against an army with banners. While legislation in the interest of health has often been liberal when some great plague has struck terror to all hearts, efforts at such times are like attempts to stay the floods of the Father of Waters when the levees have broken; or to fortify a city with the enemy in its streets. To insure success provision must antedate invasion. There must be permanent authority with power to act, to insure protection against zymotic disease.

The Marine-Hospital Service, with an executive head clothed with the energy of SurgeonGeneral Hamilton, has still further illustrated the vital importance to the nation of State Medicine. But this Service was organized for a narrow sphere of duty, and though its boundaries have been greatly enlarged, its authority comes second-hand from a department with which preventive medicine has nothing in common, save that "public health is public wealth." It is only an indirect National acknowledgment of the possibility of staying the ravages of disease.

Boards of Health have been organized in nearly every State in the Union, and wherever they have been composed of scientific sanitarians, and lifted above the narrow lines of party politics, and given authority to act, they have been active factors in the development of State Medicine. But the plagues that destroy recognize no State lines, know no State rights, and when the several States delegated to Congress the right to regulate commerce with foreign nations, and among the States, they planted better than they knew, and gave the National Legislature authority to exclude from the country the great plagues that follow commerce, and to interdict their passage from State to State; but if the Supreme Court has decided correctly, that a State has no right to prevent alcoholic liquors from crossing State lines, and being distributed in original packages, a State has no right to prevent original packages containing the germs of septic disease from being admitted and distributed among the people. To secure the full force of State Medicine there must be a National head with power to coöperate with State and local boards of health.

The constitution has also wisely provided that Congress shall have power to provide for the common defense and general welfare of the United States. Does not the general welfare include defense against the preventable diseases that cause more suffering and death than all other causesdiseases that "walk in darkness and waste at noonday," against whose poisoned arrows the citizen, in his individual capacity, is powerless to secure protection. 
The National Government, through its various departments, collects accurate statistics demonstrating the condition of commerce, manufactories, agriculture, mines, all that has hitherto been considered the important factors of political economy, but it has never realized that vital statistics are its only means of measuring the life wave of the nation, of keeping the life account, on which rests all. its political economy, and the only foundation of sanitary science. Without knowing where disease exists, its disabilities and deaths, its causes and means of prevention, there is no possibility of knowing when, where, or how to prevent or arrest it.

That eminent scientist and sanitarian, Surgeon Billings, with most commendable zeal and great labor has endeavored to evolve out of the imperfect data furnished, the vital statistics of the nation, but the result has necessarily been imperfect and unsatisfactory.

Mind and morals act through matter. To evolve healthy mental and moral action there must be healthy physical organisms. The children of the nation spend a long portion of the formative period of their lives in its schools. Its health interests demand their scientific sanitary supervision.

The National Government should also decide who may enter its life saving service. It requires the attainment of a certain standard or qualifica. tion to those who enter this service in the Army and Navy and Marine-Hospital. Are those who serve it in these departments any more important members of the body politic than the citizen who develops the industries of the nation, pays its expenses, makes and unmakes its officers? It may be said that they pay for the services they receive, and are capable of judging of the qualifications of those they employ. In this busy world few men acquire the knowledge that will enable them to judge of the qualification of a medical adviser. The general welfare of the United States demands that the government establish a standard of inedical education which shall be attained by those who enter its life saving service, that every citizen may know when his life is broken by disease or injury, that the government only permits those worthy and well qualified to administer to his wants. The fact that the citizen pays for the service does not exonerate the State from providing that he shall receive that for which he pays, and that its protection shall operate wherever its flag may float.

The medical college is responsible for medical education. While great honor is due to the distinguished men who, without State or National aid, have built up their medical schools, advanced the standard of medical education and performed the most important educational service known to the nation, the preparation of those who have charge of the life and health of the people, they have too often been compelled to snatch their lecture hours from an exacting and poorly paid practice, and to lecture without the aid of the original investigation and research essential to true progress; and unfortunately, in many States, any half dozen citizens can secure a charter for a medical school and graduate whomsoever they will. Does not "the general welfare" demand that the National Government shall establish a standard of qualification, and that the State shall provide such aid to this important branch of education as will enable teachers to devote themselves to its interests?

Government is as much bound to protect the citizen against ignorant pretenders in medicine as against preventable disease, and as much bound to extend protection against disease as against death from any other cause. This can only be done through provision for original research in the investigation of disease.

While progress in preventive medicine has been slow, perhaps because of the work of medical philanthropists, who in preventing disease have limited the income of a profession that lives by curing disease, have done the work for nothing, gone afoot and paid their own fare, the progress has been sufficient to demonstrate the importance of a National department that will not only utilize the knowledge already acquired, but prosecute such further investigations as will secure richer blessings.

The enlightened statesman knows that the strength of a nation lies in the strength of its people, and that the highest function of law is the protection of their life, health and development, that "public health is public wealth." When he comprehends that the great epidemics that destroy mankind, causing untold suffering and immeasurable financial loss, are amenable to State Medicine, may we not believe that the $\mathrm{Na}$ tional Government will establish $A$ Department of Public Health, under whose protecting æois it will gather the Marine-Hospital Service, the Bureau of Education, of Vital Statistics and of Animal Diseases, the Climatological and Signal Service, all that pertains to the health and development of the people, providing that, as in the Army and Navy, its appointments shall be preceded by thorough examination and made for life. In such a department there would be enrolled a body of scientists unequalled in the world, working in harmony for the highest interests of mankind-the prevention of disease, the preservation of life and the uplifting of humanity, giving dignity to State Medicine and the highest possible physical, intellectual and moral development to the nation. The most hopeful event during the past year is that a bill looking to this end was introduced into Congress. Such a department devoted to original research and lifted above political mutations, guided by the 
energy and intelligence of a Hamilton, a Rauch or an Eaton, will be an honor to the nation and a blessing to the world, and will hasten the day when preventive medicine and surgery will well nigh cover the field of medicine, when health will be the rule and disease the rare exception, when "The days of man shall be three score years and ten and if by reason of strength fourscore years," nay, five-score years, five times the length of his development period.

\section{ORIGINAL ARTICLES.}

\section{THE GROWING IMPORTANCE OF CHEM- ICAI, STUDIES IN MEDICAL EDU. CATION AND IN MEDICAL RESEARCH. \\ Read in the Section of the Practice of Nedicine and Physiolog $v$ at the the Forty-sccond Annual Meeting of the American Medical Association, at Washington, D.C.. May 5, 780 I. BY VICTOR C. VAUGHAN, M.D., OF ANN ARBOR, MICH.}

Gentlemen of the Section:-The object which I have in view in the selection of this subject is to call your attention to the present importance of chemical studies in the elucidation of medical problems. Chemical theories and discoveries have frequently in the past been of service to medicine, but they offer much greater promises for the future. With the past services you are familiar, and I desire to point out some of the most important problems which are now being investigated or which only await careful study.

The Chemistry of the Animal Cell.-With the form and size of the various cells of the animal body, both in health and in disease, we are fairly acquainted, but we must remember that these nltimate entities of life have also a physiological and a chemical history. Their function, as well as their form, is deserving of study. Upon what do they feed? What is the nature of their secretions and excretions? These and many other questions pertaining to their life history are worthy of study.

The diverse ways in wbich the various cells of the body and the several parts of the same cell are affected by staining reagents suggest important differences in chemical composition. The work of Miescher ${ }^{1}$ and $\mathrm{Kossel}^{2}$ has given us much valuable information concerning the composition of the nucleus of the cell. They have shown that certain compounds exist as characteristic constituents of the nuclei. These belong to the proteids, but differ from other members of this group inas-

I Med. Chem. Untersuchungen von Hoppe-Seyler, S. 44I, 502 Archiv. f. Anat. und Physiology, $188 \mathrm{r}$. Anatom. Abthei1, S. 193.

${ }_{2}$ Zeitschrift f, physiology chemic, B. 3 S. $284 ;$ B. 4 , S. 220; B. 5, S. 152 and $267 ;$ B 6, S. $422 ;$ B. 7 , S. 7 ; B. 8, S. 511 ; B. 10, S. 248. much as the albumin molecule is not free, but combined with phosphoric acid. This combination is exceedingly loose and can be broken up by boiling with water. In fact decomposition occurs at ordinary temperature if the compound is kept moist. This substance has been called by Miescher nuclein. It has been generally supposed that the phosphoric acid in the body exists as inorganic salts. This is true of the most of that contained in the bones, muscles and blood, but not of that of the glandular organs. Kossel has shown that from 60 to 75 per cent. of the total phosphoric acid in the spleen exists as nuclein, while from 30 to 50 per cent. of that of the liver, and 50 per cent. of that of the pancreas is found in the same combination. The smaller the proportion of nucleated cells in any tissue, the smaller is the amount of nuclein. In the muscle of the adult animal the amount of phosphoric acid in combination with albumin is only 7 per cent. of the total phosphoric acid.

It will be seen from the above that the amount of organically combined phosphoric acid is a measure of the nuclear substance in a given tissue, and this can be isolated and weighed, thus giv. ing a more exact estimate than that obtained by counting the nuclei under a microscope. This procedure can be mađe serviceable not only in physiological but in pathulogical work. Thus, Kossel finds that while the amount of nucleinphosphoric acid in normal blood is too small to admit of quantitive determination, as much as 5 I per cent. of the total phosphoric acid in leucocy thæmic blood may exist in this form. Again, in the examination of pus, the chemical method will detect degenerative changes in the corpuscles before they can be recognized by the microscopical examination of unstained specimens.

However, albumin and phosphoric acid are not the only constituents of the nuclei. Nuclein, on being artificially decomposed, furnishes certain basic substances, as adenine, guanine, hypoxanthine and xanthine, which are characterized by the large amount of nitrogen which they contain. Adenine contains no oxygen, is a polymer of hydrocyanic acid, and indicates by its reactions that it belongs to the cyanogen compounds. Schindler ${ }^{3}$ has shown that 7 per cent. of the total nitrogen of the thymus gland exists in adenine. The large amount of hypoxanthine and xanthine in letucocythæmic blood arises from the decomposition of the nuclein.

Nuclein seems to be an acid which in the various tissues is combined with a base of somewhat variable composition. This basic substance is called by Kossel, "histon," and it has been designated by Miescher as a "basic pepton."

The above mentioned facts throw much light upon phenomena which have long been observed, but not understood, by histologists. The marked

3 Berliner k1in. Wochenschrift, 1889 , s. 4 I6. 